UDC 519.652:519.254: 004.932.2(045)

Ph. Pristavka, A. Assaul, E. Nichikov, A. Rogatuk

National Aviation University

\title{
AUTOMATION OF DATA FROM VIDEO CAMERAS OF SMALL AND MEDIUM-SIZED UNMANNED AERIAL VEHICLES PROCESSING
}

The information technology for graphical data from unmanned aircraft real time processing was developed. Information technology embodied in the form of an automated system can be used in the development of a second external pilot workplace. The structure and functionality of the automated system, considered used image processing algorithms and video, were described.

Key words: processing image data; processing video data; unmanned aircraft; real-time processing.

Разработана информационная технология обработки фото- и видеоданных с борта беспилотного летательного аппарата в режиме реального времени. Информационной технологии, реализованной в виде автоматизированной системы, можно найти применение при разработке рабочего места второго внешнего пилота. Описана структура и функциональные возможности автоматизированной системы, рассмотрены использованные алгоритмы обработки изображений и видео.

Ключевые слова: обработка фотоданных; обработка видеоданных; беспилотный летательный аппарат; режим реального времени.

Розроблено інформаційну технологію обробки фото- та відеоданих з борту безпілотного повітряного судна в режимі реального часу. Інформаційну технологію реалізовано у вигляді автоматизованої системи, що може знайти використання при розробці робочого місця другого зовнішнього пілота. Описано структуру та функціональні можливості автоматизованої системи, розглянуто використані алгоритми обробки зображень та відео.

Ключові слова: обробка фотоданих; обробка відеоданих; безпілотне повітряне судно; режим реального часу.

Introduction. Nowadays there is active development of unmanned aerial vehicles (UAVs) of small and medium type used by some military and civilian services for analysis in complex terrain conditions all over the world [1-5]. In addition to issues relating directly to the structure and characteristics of the aircraft, data processing purpose, particular, video from $\mathrm{UAV}$ processing is also very impotent.

C Pristavka Ph., Assaul A., Nichikov E., Rogatuk A., 2014 
Using small and medium-sized UAV flying at a speed of over $60 \mathrm{~km} /$ $\mathrm{h}$ is specific. Because of the low altitude, it is quite difficult for operator to analyze the captured video. Relevant is the development of systems that can help to isolate suspicious objects, for enable external pilots quickly respond to changes recorded by the hardware video sensors. Also after highlighting a particular region, it may be useful to impose video frame on the geo map that allows operator focus on the terrain.

The need to provide real-time processing, reliability and versatility make it very difficult to build high-performance systems for digital video stream processing. This is due to the fact that the known approaches generally algorithmically complex, which leads to additional hardware costs and slow processing. Requirements to improve performance are relevant in the context of the ever-growing needs of processing an increasing amount of data. Providing real-time processing is highly impotent, so it is important to choose technologies which support multiple calculations and mathematical algorithms which are easy to parallelize [6].

Analysis of technologies. Let the data from the UAV comes in the form of streaming video and information about the position of the aircraft (GPS-coordinates). Any data processing must be performed in the background, which will allow operator to quickly react on situation changes.

It is necessary to select the technology that would enable a real-time processing of streaming video, flexible enough for the implementation of the developed algorithms, and would not need special equipment.

OpenCV $[7,8]$ is popular open source library of algorithms of computer vision, image processing and numerical algorithms for general-purpose, which is implemented in the $\mathrm{C} / \mathrm{C}++$, is also being developed for Python, Java, Ruby, Matlab, Luata and other languages [9]. Using of NVIDIA graphics processors [10] with CUDA [11] can significantly increase the computational performance in software for UAVs. The disadvantage of this technology is requirement of a specific type of graphics processors.

OpenCL framework can be used for creating computer programs related to parallel computing on the different graphics and central processing units and $[12,13]$. OpenCL provides instruction-level and data-level parallelism, and is an implementation of GPGPU technique.

The purpose of the article is the introduction of the information technology (IT) for processing the data received from the cameras of UAV, which enables operators of decision-making systems to quickly respond on changes. This technology can be used to create the working space of the second UAV pilot.

Information technology. The National Aviation University (Ukraine) IT of graphical data processing from UAV's cameras was developed [14]. It consists of the methods of analysis of image data and software complex 
for automated data processing, which allows operator to perform the following tasks:

1. Process and display UAV path of flight.

2. Determining the position and marking suspicious objects.

3. Real time recognition of foreign object in the video obtained from the UAV.

4. Output the array of suspicious textures.

5. Transfer flight commands to UAV.

6. Imposition of frames from video sequence on a geomap using the methods orthorectification.

Software developed by the authors (UASAnalizer) receives and processes from UAV following data: current geographic coordinates, flight path, photos and videos. UASAnalizer based on a modular architecture. Modules have their own interface and can be used separately from the main program.

Most of the components have been implemented in the programming language $\mathrm{CH}$, but the video processing module has been designed as a separate component which is based on Adobe Flex. Video processing is performed in two independent streams. For interaction between Adobe Flex and C \# library AxShockwaveFlashObjects.dll was used [15].

Based on the methods developed by authors [16], video processing module was implemented. It includes real time identification procedure of a foreign object, search and detecting moving targets in the video.

Software implementation of this module is designed for multimedia platform Adobe Flash [17]. Adobe Flash is chosen because of the wide range of operating systems on which the application is supported and the possibility of fast video streaming implementation [17]. Launching applications is supported both: through Adobe Flash Player [18] (integrated system), and through the Adobe AIR [19] (autonomous system). This system allows the use of cross-platform data processing and analysis of digital video on most modern operating systems.

ActionScript Virtual Machine 2 (AVM2), which is based on the Adobe Flash Player and Adobe AIR, has reach possibilities for processing and display graphic content. In particular, it is possible to use shader filtering of video sequence by the Pixel Bender technology [20]. In addition AVM2 provides tools for creating applications which use parallel computing model [21].

So, given the cross-platform (AVM2 supports a family of platforms: Microsoft Windows, Mac OS X, Linux, Android, BlackBerry Tablet OS, BlackBerry 10), extensive work with the graphical data (integrated graphics data filtering, and the ability to create software shaders) streaming video and support of parallel execution model, Adobe Flash platform is an effective tool for creating systems of digital video streaming and real time processing. 
To accomplish these tasks, there are two modes: detection and accumulation of typical video textures and allocation of foreign objects. Detection mode provides object recognition for a given reference pattern and maintenance of the captured object (target).

During storage of textures, in each video frame chosen number of test samples which are processed and analyzed. As a result, each sample belongs to one of the groups:

1 ) is stored as a standard on which there is typical for this video is a simple texture, such as texture, «grass», «sandy road»;

2 ) is stored as a complex pattern in which there are a few typical (simple) for the current video textures, such as texture «in the bush»;

3 ) is saved and displayed to the user on the screen as having a foreign texture, such as texture «cars on the sandy road», «house in the woods».

The user does not specify any data source, the procedure runs with the initial settings that can be changed in the future: the size of the control samples, standards cleaning array, etc. The steps of the identification of the foreign object are shown on the diagram (Fig. 1).

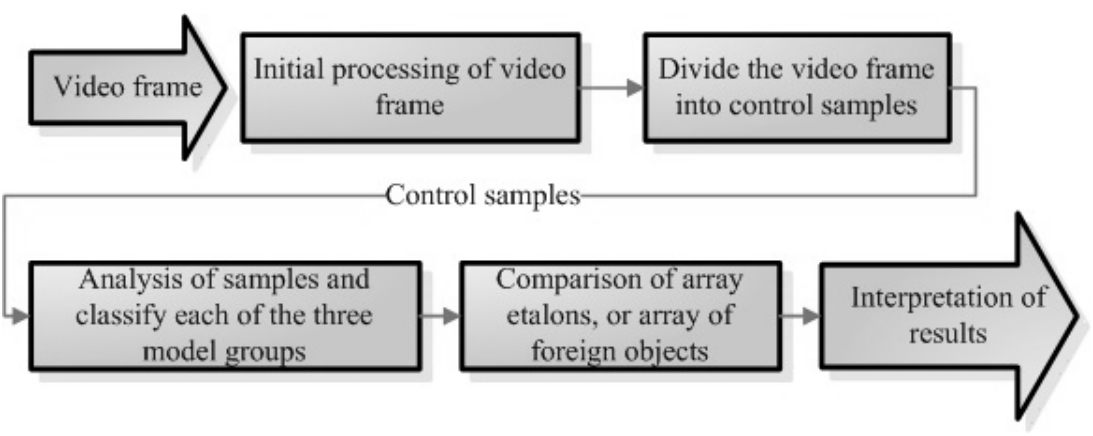

Figure 1. The general scheme of identification foreign object procedure

During pre-processing the data from current video frame are treated for further use in other stages of processing, and sequential analysis. The main phase of identification is the comparing each test texture with the accumulated textures (with an array of standards or an array of foreign objects), as the result of analysis system concludes the existence and location of a suspicious object in the video frame.

Detection mode is performed after the user-defined target. The target can be selected from an array of accumulated textures or pre-stored samples. The steps of the detection of moving targets are given in the diagram (Fig. 2).

Current video frame data is processed on pre-treatment step and a step of partitioning the field (control samples). Analysis of the results of the 
comparison of each test sample with a reference (target), allows to determine the location of the current video frame - new coordinates of the intended target.

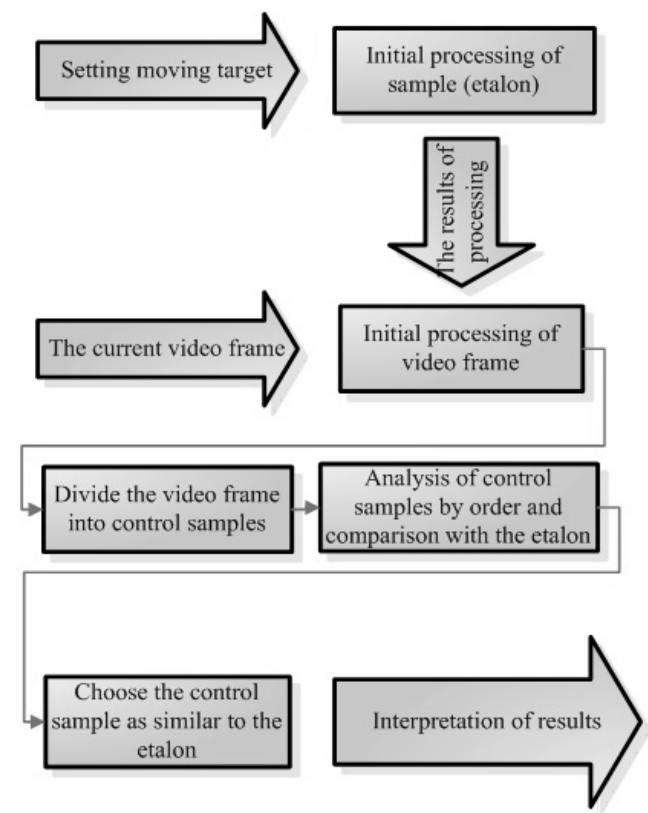

Figure 2. The general scheme of the moving target detection procedures

Within the information technology graphics processing task of imposing individual video frames on the map, which can be solved by the methods of orthorectification [22].

For an aerial photo orthorectification system needs to calculate the transformation parameters using the image points and the corresponding points on the map. Depending on the type of conversion, the required number of points determines the transform coefficients. For example, for a perspective transformation four pairs of reference points are required [22].

At the moment, the authors developed algorithms of perspective, bilinear and polynomial transformations using spline transformations on the basis of local polynomial interpolation splines [23, 24].

Description of the interface developed software UASAnalizer. The main window of UASAnalizer visually divided into two areas: on the left the area of the video and display the results of the processing panel, on the right - the map area. 
When you click on the «Start» video from the UAV starts playing, and the map shows current location of aircraft. General view of the user interface is shown on the figure (Fig. 3).

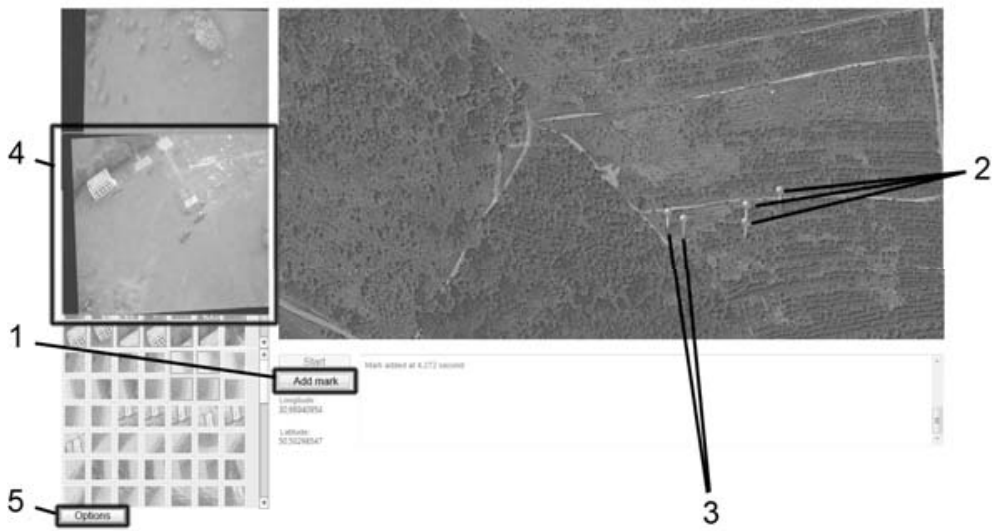

Figure 3. Flight data processing. 1 - add mark button, 2.3 - marks on the map, 4 - the frame of video, 5 - the button to open the options panel

The user can put a mark on the map at the current time by pressing «Add Mark» button (Figure 1, 2, 3).

Below the video display area placed panels, which are provided with the results of the identification of objects in the video similar to the target object. Since the procedure is performed in two independent lines, the results are displayed in two lists. The objects can be manipulated with the following actions:

1) right click on the object: put a note on the map with the location of the aircraft at the time the sample was captured (Figure 3);

2) left-click on the object: shows window with a video frame received at the time the sample was captured (Figure 4). location.

After clicking on the mark the UAV is commanded to fly on the given

The button «Options» (Figure 5) allows you to go to the options panel, which allows: define the sizes of control samples, thresholds, etc., change the mode of the video processing module («auto» or «detect»), to clean up the reference array of textures and download new samples.

Orthorectification module allows automated tying shots to geographic coordinates to create the actual maps. The module is implemented as a single term. Interaction with the main part of the software package is based on tiles. Working window of the module is represented by three areas: 1 - the area of the image selection, 2 - working area, 3 - results area (Fig. 4). 


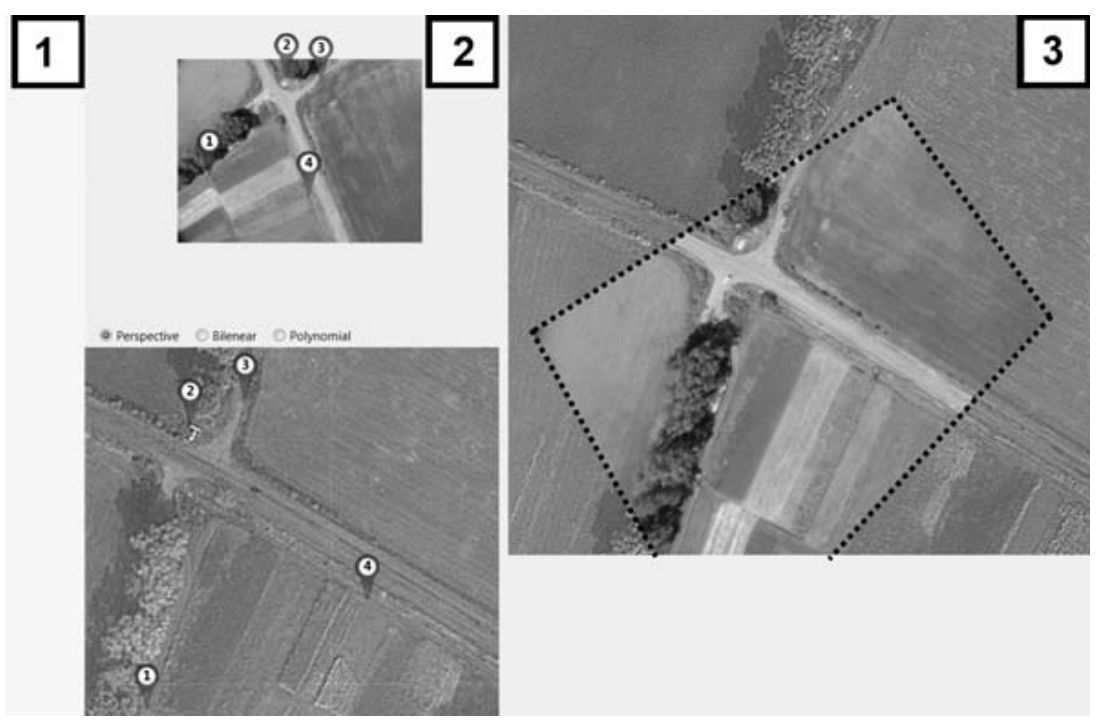

Figure 4. Binding image from the flight to geomap. 1 - select the area for bind, 2 - working area, 3 - results

Images from UAV and corresponding geographical coordinates are uploaded to the specific database. If it is necessary, the user can attach an image to the geo map. To do this: choose an image, select the type of conversion, set control points using the mouse. Conversion calculations and displaying the results are performed automatically after installing the required number of points.

Currently implemented perspective ( 4 points), bilinear ( 4 points) and polynomial (6 points) transformations. An example of binding the image with the perspective transformation is shown on figure 4 . With the help of linked images you can build a separate map layer that is displayed in the map area of the main program.

Conclusions and further research. Presented software UASAnalizer within the information technology of image data from UAV which allows operator to perform the following tasks: determining the current position of UAV and display the trajectory of its flight, the loaction of suspicious objects and picking them with marks, recognition of foreign objects in the video, overlay video sequence of individual frames on a map using methods orthorectification.

The methods used for computing allow multiple threads to substantially increase the processing speed and allows the real time processing of video. 
The implementation of information technology can be used to create a workplace for second external pilot of UAV.

The software has been tested using data from UAV M - 10 «OKO», which is constructed in center of unmanned aircraft development «Virage», National Aviation University, Ukraine.

Further research: developing methods for automate the creation of maps, the organization better interact with the UAV, etc.

\section{Reference}

1. Boerand J. F. Small Unmanned Aircraft Systems (UAS) for Law Enforcement Theuse of UAS within the Dutch Policeforces / J. F. Boerand G. Ten Buuren // UAS 2011 Conference organized by UVS International, Paris, France, 14-16 june 2011. NLR - TP - $2011-283 \mathrm{p}$.

2. Unmanned aircraft navigation for shipboard landing using infrared vision / O. A. Yakimenko, I. I. Kaminer, W. J. Lentz, P. A. Ghyzel // Aerospace and Electronic Systems, IEEE Transactions on. - Vol. 38, Issue: 4-2002. - 1181-1200 p.

3. Vision-based road-following using a small autonomous aircraft / E. Frew, T. McGee, ZuWhan Kim, Xiao Xiao, S. Jackson, M. Morimoto, S. Rathinam, J. Padial, Sengupta, Raja // Aerospace Conference, 2004. Proceedings. 2004 IEEE. Vol. 5. - 2004. - 3006-3015 p.

4. Haiyang Chao. AggieAir: Towards Low-cost Cooperative Multispectral Remote Sensing Using Small Unmanned Aircraft Systems, / Haiyang Chao, Austin M. Jensen, Yiding Han, YangQuan Chen and Mac McKee // Advances in Geoscience and Remote Sensing, Gary Jedlovec (Ed.). - 2009. - InTech, DOI: 10.5772 / 8333. URL: http: // www.intechopen.com / books / advances-in-geoscience-and-remote-sensing / aggieair-towards-low-cost-cooperative-multispectral-remote-sensing-using-small-unmanned-aircraft-sys.

5. Kenzo NONAMI. Prospect and Recent Research \& Development for Civil Use Autonomous Unmanned Aircraft as UAV and MAV / Kenzo NONAMI // Journal of System Design and Dynamics. - Vol. 1. - No. 2. - 2007. - 120-128 p.

6. Herlihy M. The Artof Multiprocessor Programming: Book / M. Herlihy, NirShavit. - Burlington: Morgan Kaufmann Publishers, 2008. - 505 p.

7. Программный комплекс для автоматизации научных исследований в области создания перспективных систем навигации беспилотных летательных аппаратов по данным видеонаблюдения / Б. А. Алпатов, П. В. Бабаян, Ю. С. Коблов и др. // Вестник РГРТУ. - Рязань, 2012. - № 2 (вып. 40).

8. Hing J. T. Improving Unmanned Aerial Vehicle Pilot Trainingand Operation for Flyingin Cluttered Environments / J. T. Hing, K. W. Sevcik, P. Y. Oh //Intelligent Robots and Systems - 2009. - P. 5641-5646. - DOI: 10.1109 / IROS.2009.5354080

9. Bradsky G. Learning OpenCV - O’Reilly / G. Bradsky, A. Kaehler. - 2008. C. 1. - ISBN 978-0-596-51613-0

10. NVIDIA: http: // nvidia.com.

11. CUDA ZONE: https: // developer.nvidia.com / category / zone / cuda-zone

12. OpenCL: http: // opencl.ru /

13. ISO / IEC 9899:1999 / Cor 3:2007 от 2007-11-15: http: // www.iso.org / iso / home / store / catalogue_ics / catalogue_detail_ics.htm?csnumber $=50510$

14. Pristavka Ph. A. Components of Information Technology Processing of Data Obtained from Unmanned Aerial Vehicle / Ph. Pristavka, A. Assaul, E. Nichikov, 
A. Rogatuk // Proceedings The Fifth World Congress «Aviationinthe XXI-stCentury» «SafetyinAviationandSpace Technologies». - Vol. 2. - Kyiv, 2012. - 2.21-2.25 p.

15. Using the external API withan ActiveX container: http: // help.adobe.com / en_US / ActionScript / 3.0_ProgrammingAS3_Flex / WS5b3ccc516d4fbf351e63e3d$11 \overline{8} \mathrm{a} 9 \mathrm{~b} 90204-7 \mathrm{cb} 0 . \mathrm{html}$

16. Приставка П. О. Математичне забезпечення розпізнавання та супроводу рухомого об'єкту в режимі реального часу для відео / П. О. Приставка, А. А. Рогатюк // Вісн. НАУ. - 2013. - № 2 (55). - C. 141-148.

17. Adobe Flash Platform: http: // www.adobe.com / platform / whitepapers / platform_overview.pdf.

18. Adobe Flash Player: http: // www.adobe.com / ru / products / flashplayer.html.

19. Adobe AIR: http: // www.adobe.com / ru / products / air / tech-specs.html.

20. Pixel Bender Reference. Adobe Systems Incorporated - 2009. : http: // www. adobe.com / content / dam / Adobe / en / devnet / pixelbender / pdfs / pixelbender_reference.pdf

21. Adobe ActionScript 3.0 Platform: http: // help.adobe.com / ru_RU / FlashPlatform / reference / actionscript / 3 / flash / system / Worker.html.

22. Mallon John. Projective Rectification from the Fundamental Matrix / John Mallon, Paul F. Whelan // Imageand Vision Computing archive. - Vol. 23. - Issue 7, Butterworth-Heinemann Newton, MA, USA, July, 2005. - P. 643-650.

23. Приставка П. О. Поліноміальні сплайни при обробці даних / П. О. Приставка. - Д.: Вид-во Дніпропетр. ун-ту, 2004. - 236 с.

24. Нічіков С. П. Орторектифікація знімків, отриманих з безпілотних повітряних суден малого та середнього типу, із прив'язкою за реперними точками / Є. П. Нічіков // Проблеми інформатизації та управління. - К., 2012.

Надійшла до редколегії 25.09.14 